\title{
ANALISIS LOGAM TIMBAL (Pb) DAN BESI (Fe) DALAM AIR LAUT DI PELABUHAN DESA PARANGGI KECAMATAN AMPIBABO
}

\author{
Analysis of Lead (Pb) and Iron (Fe) in Sea Water at Seaport in Paranggi Village \\ District of Ampibabo
}

*Fiskanita, Baharuddin Hamzah, dan Supriadi

Pendidikan Kimia/FKIP - Universitas Tadulako, Palu - Indonesia 94118

Received 03 September 2015, Revised 05 October 2015, Accepted 04 November 2015

\begin{abstract}
Determination of concentration of lead $(\mathrm{Pb})$ and iron $(\mathrm{Fe})$ has been conducted in sea water in Paranggi village, district of Ampibabo. The method used is spectrophotometry, namely atomic absorption spectrophotometer (AAS). Sea water sample is taken in the morning with a 3-point sampling, which is at a distance of $\pm 5 \mathrm{~m}, 10 \mathrm{~m}$ and $15 \mathrm{~m}$ respectively. The 3-point sampling is from the port side of the back end of the ship and the port end of the backrest ship at a distance of $\pm 5 \mathrm{~m}$ ahead. Analysis of Pb level is measured at a wavelength of $217 \mathrm{~nm}$ and $F e$ at a wavelength of $248.3 \mathrm{~nm}$. Result shows that $\mathrm{Pb}$ levels at point $A$ is $0.4869 \mathrm{mg} / \mathrm{L}$, at point $B$ is 0.5304 , and at point $C$ is 0.4869 while for the $\mathrm{Fe}$ levels shows that at point $A$ is 0.3073 , at point $B$ is 0.2652 , and at point $C$ is 0.2863 . The range of the concentration of $P b$ is between 0.4869 to $0.5304 \mathrm{mg} / \mathrm{L}$. This concentration is higher when compared with the $N A B P b, 0.025 \mathrm{mg} / \mathrm{L}$. Furthermore, the range of the concentration of Fe is from 0.2652 to $0.3073 \mathrm{mg} / L$. Similarly to $P b$ result above, this concentration is higher when compared with the NAB $\mathrm{Fe}, 0.01 \mathrm{mg} / \mathrm{L}$.
\end{abstract}

Keywords: Lead (Pb), Iron (Fe), Sea Water, Atomic Absorption Spectrophotometer (AAS)

\section{Pendahuluan}

Seiring dengan perkembangan kota dan kemajuan industri yang semakin pesat ternyata dapat memberi pengaruh buruk terhadap lingkungan terutama lingkungan laut yang banyak orang anggap sebagai tempat pembuangan akhir berbagai jenis limbah, baik limbah industri maupun limbah rumah tangga. Limbah yang masuk ke laut tersebut mengandung berbagai macam polutan termasuk logam berat seperti timbal $(\mathrm{Pb})$, besi $(\mathrm{Fe})$, kromium $(\mathrm{Cr})$, kadmium $(\mathrm{Cd}) \mathrm{dan}$ lain-lain. Logam ini pada mulanya berada dalam konsentrasi kecil namun apabila limbah yang masuk semakin banyak, maka secara perlahan-lahan logam-logam tersebut akan mengakibatkan pencemaran terhadap lingkungan laut (Bustanul, dkk., 2012). Keberadaan logam terutama logam berat dalam lingkungan laut dengan konsentrasi di atas normalnya, selain dapat mempengaruhi kelangsungan hidup biota laut juga dapat

*Correspondence:

Fiskanita

Program Studi Pendidikan Kimia, Fakultas Keguruan dan Ilmu Pendidikan, Universitas Tadulako

email: ickafiskanita012@gmail.com

Published by Universitas Tadulako 2015 menyebabkan perubahan fungsi fisiologis dari logam itu terhadap mahluk hidup. Hal ini terjadi karena logam berat mempunyai sifat komulatif, akibatnya dapat berada dalam mahluk hidup dengan kosentrasi yang mematikan atau berefek kronis (Rahman, 2006).

Logam berat yang masuk ke perairan, baik di sungai maupun lautan dipindahkan dari badan airnya melalui tiga proses yaitu pengendapan, adsorbsi, dan absorbsi oleh organisme-organisme perairan (Perez-Lopez, dkk., 2003). Pada saat buangan limbah industri masuk ke dalam suatu perairan maka akan terjadi proses pengendapan dalam sedimen. Hal ini menyebabkan konsentrasi bahan pencemar dalam sedimen meningkat (Begum, dkk., 2009). Logam berat yang masuk ke dalam lingkungan perairan mengalami pengendapan, pengenceran dan dispersi, kemudian diserap oleh organisme yang hidup di perairan tersebut. Pengendapan logam berat di suatu perairan terjadi karena adanya anion karbonat hidroksil dan klorida (Murtini \& Rosmawaty, 2006).

Laut merupakan ekosistem perairan yang dapat berinteraksi dengan berbagai kegiatan manusia yang ada di dalamnya, tidak terkecuali 
perairan laut sekitar pelabuhan desa Paranggi, kegiatan manusia yang di maksud adalah aktivitas kapal laut yang keluar masuk dermaga/ pelabuhan guna melakukan bongkar muat ikan, yang dapat meningkatkan pendapatan bagi sebagian masyarakat terutama nelayan, dan aktivitas lainya seperti kegiatan pergantian bahan minyak pelumas, pengisian bahan bakar (Gultom, dkk., 2011). Kegiatan-kegiatan tersebut berpotensi menghasilkan limbah yang mengandung logam-logam berbahaya seperti timbal dan besi (Amriani, dkk., 2011).

Berdasarkan aktivitas yang di sekitar pelabuhan desa Paranggi, kuat dugaan bahwa kualitas air laut sekitar pelabuhan desa Paranggi telah mengalami perubahan baik aspek kualitas fisik, kimia maupun aspek biologisnya disebabkan oleh limbah padat dan cair berupa pelumas minyak bekas, atau tumpahan minyak dari kebocoran kapal, oleh karna itu kelestarian lingkungan laut dari bahan tersebut perlu terus dikontrol (Alamsyah, 2010).

Proses masuknya senyawa hidrokarbon dan logam-logam berat melalui media minyak dan produk-produknya atau melalui limbah cair yang mengandung logam berat yang dibuang kelaut, membentuk emulsi pada permukaan air kemudian mengalami agregasi, oleh pembentukan emulsi secara kontinyu sehingga berat melekulnya menjadi besar dan akhirnya jatuh ke dalam air sebagian masuk kedalam sedimen (Siaka, 2008).

Berdasarkan sudut pandang toksikologi, logam berat dapat di bagi menjadi dua jenis. Jenis pertama adalah logam berat ensial dimana keberadaanya dalam jumlah tertentu sangat dibutuhkan oleh organissme hidup, namun dalam jumlah yang berlebihan dapat mesnimbulkan efek racun, contoh logam berat ini adalah $\mathrm{Fe}$ keberadaan besi dalam air laut juga dapat bersumber dari pengkaratan kapalkapal laut dan tiang-tiang pancang pelabuhan yang mudah berkarat. Sedangkan logam jenis kedua adalah logam berat non ensial atau beracun, di mana keberadaanya dalam tubuh belum diketahui manfaatnya atau bahkan dapat bersifat racun seperti $\mathrm{Pb}$ secara alamiah timbal dapat masuk kedalam badan perairan melalui pengkristalan timbal di udara dengan bantuan air hujan (Sudarmaji, dkk., 2006).

\section{Metode}

Alat dan Bahan

Alat-alat yang digunakan yaitu seperangkat alat SSA Spektra AA 932, botol berwarna gelap $10 \mathrm{~mL}$, labu ukur $1000 \mathrm{~mL}$ dan $50 \mathrm{~mL}$, gelas ukur $50 \mathrm{~mL}$, pipet tetes, $\mathrm{pH}$ meter, botol semprot, corong, pipet ukur, karet penghisap dan kertas label. Sedangkan bahan yang digunakan yaitu air lait, aquades, asam nitrat $\left(\mathrm{HNO}_{3} 69 \%\right.$ ) smart lab, $\mathrm{Pb}\left(\mathrm{NO}_{3}\right)_{2}$ Riedel-de hean, $\mathrm{Fe}\left(\mathrm{NO}_{3}\right)_{2}$ merck, $\mathrm{HNO}_{3} 1 \mathrm{M}$ smart lab, $\mathrm{NH} 4 \mathrm{OH} 1 \mathrm{M}$ merck dan kerta saring.

\section{Cara Kerja}

Pada pengambilan sampel air laut dilakukan pada pagi hari dengan 3 lokasi tempat pengambilan sampel yaitu pada jarak $\pm 5 \mathrm{~m}, 10 \mathrm{~m}$ dan $15 \mathrm{~m}$ dari ujung samping pelabuhan sandaran kapal dan dari ujung pelabuhan sandaran kapal mengambil jarak $\pm 5 \mathrm{~m}$ ke depan. Kemudian sampel air laut tersebut ditetesi sebanyak $1 \mathrm{~mL}$ dengan larutan asam nitrat $\left(\mathrm{HNO}_{3}\right) 65 \%$. Dalam pembuatan larutan induk $\mathrm{Pb}, 100 \mathrm{ppm}$, ditimbang 0,159 gram $\mathrm{Pb}\left(\mathrm{NO}_{3}\right)_{2}$ dan dilarutkan dalam asam nitrat pekat, kemudian ditambahkan aquades sampai tanda batas dalam labu ukur 1000 $\mathrm{ml}$. Untuk pembuatan larutan induk $\mathrm{Fe}, 100$ ppm ditimbang 0,322 gram $\mathrm{Fe}\left(\mathrm{NO}_{3}\right)_{2}$ dan dilarutkan dalam asam nitrat pekat, kemudian ditambahkan aquades sampai tanda batas dalam labu ukur 1000 mL. Dari larutan standar $\mathrm{Pb}$ dan Fe 100 ppm dibuat deret kerja 0 ppm; 0,05 ppm; 0,1 ppm; 0,5 ppm; 1,0 ppm; $1,5 \mathrm{ppm}$; dan $2 \mathrm{ppm}$. Setelah itu dibuatkan kurva kalibrasi untuk kedua logam tersebut. Setelah itu sampel air laut di ambil sebanyak $10 \mathrm{~mL}$ kemudian pHnya di atur sampai 5 lalu dianalisis dengan Spektrofotometer Serapan Atom pada panjang gelombang $217 \mathrm{~nm}$ untuk logam timbal dan panjang gelombang 248,3 nm untuk logam besi (Ika, 2012).

\section{Analisa Data}

Berdasarkan hasil pengukuran yang diperoleh menggunakan alat Spektrofotometer Serapan Atom (SSA), maka data yang diperoleh dapat dihitung menggunakan persamaan: $\mathrm{y}=\mathrm{a}$ + bx dimana y adalah variabel terikat, a adalah konstanta, $\mathrm{b}$ adalah koefisien regresi dan $\mathrm{x}$ adalah variabel bebas.

\section{Hasil dan Pembahasan}

Penelitian ini dilakukan untuk menentukan konsentrasi logam timbal $(\mathrm{Pb})$ dan besi $(\mathrm{Fe})$ dalam air laut di pelabuhan desa Paranggi Kecamatan Ampibabo 


\section{Konsentrasi logam timbal (Pb) pada Sampel}

Tabel 1. Data analisis timbal $(\mathrm{Pb})$ pada larutan standar dengan menggunakan alat SSA.

\begin{tabular}{|c|c|c|c|}
\hline No & Nama & $\begin{array}{c}\text { Konsentrasi } \\
\quad(\mathrm{ppm})\end{array}$ & Absorbansi \\
\hline 1. & Blangko & 0 & $-0,002$ \\
\hline 2. & Standar 1 & 0,05 & 0,006 \\
\hline 3. & Standar 2 & 0,1 & 0,018 \\
\hline 4. & Standar 3 & 0,5 & 0,085 \\
\hline 5. & Standar 4 & 1 & 0,130 \\
\hline 6. & Standar 5 & 1,5 & 0,240 \\
\hline 7. & Standar 6 & 2 & 0,304 \\
\hline \multicolumn{4}{|c|}{ Sampel air laut } \\
\hline 1 & Sampel $1(5 \mathrm{~m})$ & 0,4869 & 0,012 \\
\hline 2 & Sampel $2(10 \mathrm{~m})$ & 0,5304 & 0,013 \\
\hline 3 & Sampel $3(15 \mathrm{~m})$ & 0,4869 & 0,012 \\
\hline
\end{tabular}

\begin{tabular}{|l|c|c|c|}
\hline No & Nama & $\begin{array}{c}\text { Konsentrasi } \\
(\mathbf{p p m})\end{array}$ & Absorbansi \\
\hline 1. & Blangko & 0 & $-0,002$ \\
\hline 2. & Standar 1 & 0,05 & 0,006 \\
\hline 3. & Standar 2 & 0,1 & 0,018 \\
\hline 4. & Standar 3 & 0,5 & 0,085 \\
\hline 5. & Standar 4 & 1 & 0,130 \\
\hline 6. & Standar 5 & 1,5 & 0,240 \\
\hline 7. & Standar 6 & 2 & 0,304 \\
\hline & Sampel air laut & & \\
\hline 1 & Sampel 1 (5 m) & 0,4869 & 0,012 \\
\hline 2 & Sampel 2 (10 m) & 0,5304 & 0,013 \\
\hline 3 & Sampel 3 (15 m) & 0,4869 & 0,012 \\
\hline
\end{tabular}

\section{Konsentrasi logam besi (Fe) pada Sampel}

Tabel 2. Data analisis besi (Fe) pada larutan standar dengan menggunakan alat SSA.

\begin{tabular}{|c|c|c|c|}
\hline No & Nama & $\begin{array}{c}\text { Koncentrasi } \\
\text { (ppm) }\end{array}$ & Absorbansi \\
\hline 1. & Blangho & 0 & 0 \\
\hline 2. & Standar 1 & 0,05 & 0,002 \\
\hline 3. & Standar 2 & 0.1 & 0,004 \\
\hline 4. & Standar 3 & 0.5 & 0,026 \\
\hline 5. & Standar 4 & 1 & $0,0-1$ \\
\hline 6. & Standar 5 & 1.5 & 0,075 \\
\hline 7. & Standar 6 & 2 & 0.094 \\
\hline \multicolumn{4}{|c|}{ Samped air laut } \\
\hline 1 & Sampel 1 (5 m) & 0.307 & 0,014 \\
\hline 2 & Sampcl 2 (10 m) & 0.265 & 0.012 \\
\hline 3 & Sampcl 3 (15 m) & 0.286 & 0,013 \\
\hline
\end{tabular}

Wilayah perairan yang mudah tercemar oleh logam-logam berat ialah wilayah perairan air asin. Penelitian ini dianalisis menggunakan Spektrofotometer Serapan Atom. Sebelum dilakukan analisis pertama-tama sampel diambil dengan menggunakan botol yang berukuran $150 \mathrm{~mL}$ dengan tiga lokasi tempat pengambilan sampel yang masing-masing jaraknya yaitu pada jarak $\pm 5 \mathrm{~m}, 10 \mathrm{~m}$ dan 15 $\mathrm{m}$ dari ujung samping pelabuhan sandaran kapal dan dari ujung pelabuhan sandaran kapal mengambil jarak $\pm 5 \mathrm{~m}$ ke depan. Sampel di ambil pada waktu pagi hari, sampel air yang diambil kemudian ditetetsi asam nitrat $\left(\mathrm{HNO}_{3}\right)$, dimana asam nitrat berfungsi sebagai pengawet. Kemudian sampel di bawa ke laboratorium untuk dilakukan analisis dengan menggunakan alat SSA.

Selanjutnya membuat larutan standar baik untuk logam timbal atau pun besi. Setelah itu diteruskan dengan membuat deret kerja dengan perbedaan konsentrasi masingmasing. Perlakuan pada analisis logam timbal yaitu sampel air laut diambil sebanyak $10 \mathrm{ml}$, kemudian dimasukkan ke dalam gelas kimia dan pHnya diatur sampai 5 , pada penggunaan spektrofotometer, sampel yang akan di analisis harus dalam suasana asam karena proses atomisasi agar dapat berlangsung secara sempurna. Kemudian sampel dianalisis dengan menggunakan alat Spektrofotometer Serapan Atom (SSA) pada panjang gelombang $217 \mathrm{~nm}$.

Dari hasil penelitian yang telah dilakukan, dapat diketahui konsentrasi timbal yang terkandung dalam air laut setelah dianalisis dengan menggunakan alat SSA, maka diperoleh data pada Grafik 1.

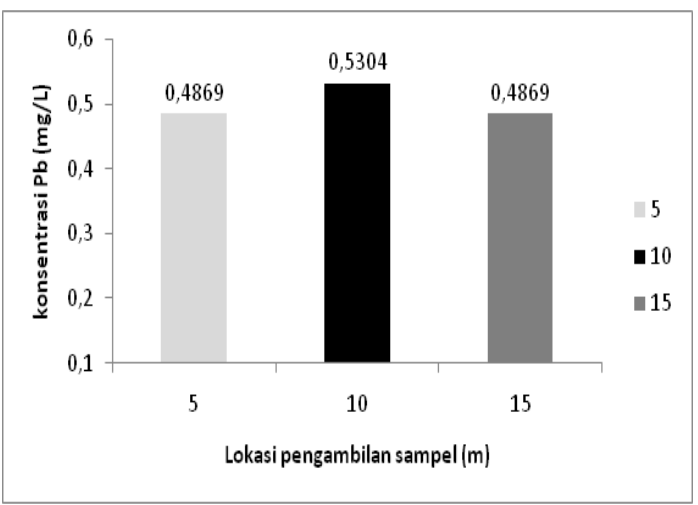

Grafik 1. Data analisis Timbal $(\mathrm{Pb})$ pada sampel dengan menggunakan alat SSA

Sampel air laut yang di ambil pada waktu pagi hari yaitu pada jarak 5 meter adalah 0,5090 $\mathrm{mg} / \mathrm{L}$, pada jarak 10 meter adalah $0,5540 \mathrm{mg} / \mathrm{L}$ 
dan pada jarak 15 meter adalah $0,5090 \mathrm{mg} / \mathrm{L}$, dari hasil perhitungan hal ini menunjukkan bahwa kadar logam timbal pada jarak 10 meter sangat tinggi. Berdasarkan nilai ambang batas (NAB) untuk kandungan logam timbal pada perairan laut $0,025 \mathrm{mg} / \mathrm{L}$. Berdasarkan hasil yang diperoleh dapat dikatakan bahwa air laut tersebut telah tercemar (Effendi, 2003).

Tingginya konsentrasi Logam timbal dalam lingkungan perairan dapat disebabkan oleh berbagai faktor yaitu aktivitas manusia seperti aktivitas pembuangan limbah rumah tangga yang mengandung logam timbal, pengikisan batuan mineral serta debu-debu logam timbal yang ada dalam lapisan udara yang kemudian terbawa turun oleh hujan, tingginya pemakaian bensin berbahan bakar timbal (Parawita, dkk., 2009). Kadar Pb yang secara alami dapat ditemukan juga dalam bebatuan sekitar $13 \mathrm{mg} /$ $\mathrm{kg}$. Khusus $\mathrm{Pb}$ yang tercampur dengan batu fosfat dan terdapat didalam batu pasir ( sand stone) kadarnya lebih besar yaitu $100 \mathrm{mg} / \mathrm{kg}$. $\mathrm{Pb}$ yang terdapat di tanah berkadar sekitar 5 - $25 \mathrm{mg} / \mathrm{kg}$ dan di air bawah tanah (ground water) berkisar antara 1- $60 \mu \mathrm{g} /$ liter (Irvan \& Rusian, 2013).

Emisi timbal bentuk gas, terutama dari buangan gas kendaraan bermotor merupakan hasil samping dari pembakaran mesin-mesin kendaraan bermotor, hal ini menyebabkan jumlah timbal di udara dari asap buangan kendaraan semakin meningkat. Emisi bentukgas yang terakumulasi diudara akan turun bersama air hujan dan akhirnya bermuara ke laut serta pembakaran bahan bakar minyak oleh kapalkapal merupakan sumbangan terbesar polusi timbal di perairan. Logam timbal merupakan salah satu bahan untuk pencampuran pada pembuatan bahan bakar sebagai anti pemecah minyak (seperti $\mathrm{Pb}$ tetraethyl dan tetramethyl) (Sudarmaji, dkk., 2006).

Logam Besi adalah logam berwarna putih keperakan, liat dan dapat dibentuk. Fe di dalam susunan unsur berkala termasuk logam golongan VIII, dengan berat atom 55,847 g.mol-1, nomor atom 26, berat jenis 7.86 g.cm-3 (Susiati, dkk., 2008) . Senyawa besi tersebut mudah larut dalam air dan segera terurai menjadi ion besi(II) dan ion besi(III). Fe merupakan unsur hara oleh tumbuhan air seperti eceng gondok. Dalam air akan tersuspensi dan berwarna kecoklatan. Suspensi yang terbentuk akan segera menggumpal dan mengendap di dasar badan air (Sustrisno, 2002).

Zat besi adalah merupakan suatu komponen dari berbagai enzim yang mempengaruhi seluruh reaksi kimia yang penting di dalam tubuh meskipun sukar diserap (10-15\%). Besi juga merupakan komponen dari hemoglobin yaitu sekitar $75 \%$, yang memungkinkan sel darah merah membawa oksigen dan mengantarkannya kejaringan tubuh (Rusmawan, dkk., 2011).

Perlakuan pada analisis logam besi yaitu sampel air laut diambil sebanyak $10 \mathrm{~mL}$ lalu disaring, kemudian dimasukkan ke dalam gelas kimia dan pHnya diatur sampai 5 kemudian sampel dianalisis dengan menggunakan alat Spektrofotometer Serapan Atom (SSA) pada panjang gelombang 248,3 nm. Dari hasil penelitian yang telah dilakukan, dapat diketahui konsentrasi besi yang terkandung dalam air laut setelah dianalisis dengan menggunakan alat SSA, maka diperoleh data pada Grafik 2.

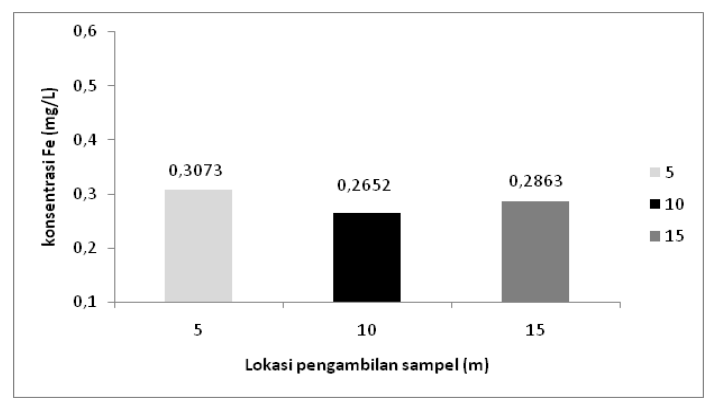

Grafik 2 Data analisis Besi (Fe) sampel dengan menggunakan alat SSA.

Dari grafik yang ada maka dilakukan analisis data dengan menggunakan persamaan regresi linear yakni $\mathrm{y}=\mathrm{a}+\mathrm{bx}$ sehingga diperoleh konsentrasi besi $(\mathrm{Fe})$ pada sampel air laut yang diambil pada waktu pagi hari yaitu pada jarak 5 meter adalah $0,3073 \mathrm{mg} / \mathrm{L}$, pada jarak 10 meter adalah $0,2652 \mathrm{mg} / \mathrm{L}$ dan pada jarak 15 adalah $0,2863 \mathrm{mg} / \mathrm{L}$, Dari hasil perhitungan ini menunjukkan bahwa kadar logam besi pada jarak 5 meter sangat tinggi. Berdasarkan nilai ambang batas (NAB) untuk kandungan logam besi pada perairan laut $0,01 \mathrm{mg} / \mathrm{L}$. Berdasarkan hasil yang diperoleh dapat dikatakan bahwa air laut tersebut telah tercemar (Effendi, 2003).

Tingginya konsentrasi besi di perairan disebabkan oleh aktivitas manusia yang terjadi di daratan yaitu buangan limbah rumah tangga yang mengandung besi dan korosi pipa-pipa air yang mengandung logam besi. Peningkatan konsentrasi besi juga disebabkan karena adanya pengikisan batuan mineral akibat hempasan gelombang dan angin serta pengkaratan kapalkapal laut dan tiang-tiang pancang pelabuhan yang mudah berkarat (Hutagalung, 2001). 
Kelebihan zat besi bisa menyebabkan keracunan dimana terjadi muntah, kerusakan usus, penuaan dini hingga kematian mendadak, mudah marah, radang sendi, cacatlahir, gusi berdarah, kanker, sirosis ginjal, sembelit, diabetes, diare, pusing, mudah lelah, kulit kehitam-hitaman, sakit kepala, gagal hati, hepatitis, hiperaktif, infeksi, insomnia, sakit liver, masalah mental, rasa logam di mulut, myasthenia gravis, nausea, nevi, mudah gelisah, Parkinson, rematik, sikoprenia, sariawan perut, sickle-cell anemia, keras kepala, strabismus, gangguan penyerapan vitamin dan mineral, serta hemokromatin (Tahril, dkk., 2011).

Pencemaran yang terjadi dalam suatu perairan khususnya pencemaran oleh logamlogam berat dapat menimbulkan banyak masalah baik yang bersifat sementara atau yang bekepanjangan. Pencemaran ini dapat dikurangi dan juga ditanggulangi, ada beberapa cara yang dapat dilakukan diantaranya dengan mengurangi penggunaan zat-zat berbahaya dan menjaga kebersihan lingkungan, maka kelangsungan hidup yang ada di darat maupun di perairan akan terjaga. Penanganan untuk pencemaran logam berat juga dapat menggunakan tumbuhan yang mampu menyerap logam berat, salah satu tumbuhan yang digunakan tersebut adalah pohon api-api (Avicennia marina) (Hutagalung, 2001).

Upaya penanganan pencemaran logam berat sebenarnya dapat dilakukan juga dengan menggunakan proses kimiawi. Seperti penambahan senyawa kimia tertentu untuk proses pemisahan ion logam berat atau dengan resin penukar ion (exchange resins), serta beberapa metode lainnya seperti penyerapan menggunakan karbon aktif, electrodialysis dan reverse osmosis. Namun proses ini relatif mahal dan cenderung menimbulkan permasalahan baru, yaitu akumulasi senyawa tersebut dalam sedimen dan organisme akuatik (perairan). Penanganan logam berat dengan mikroorganisme atau mikrobia, menjadi alternatif yang dapat dilakukan untuk mengurangi tingkat keracunan elemen logam berat di lingkungan perairan. Metode atau teknologi ini sangat menarik untuk dikembangkan dan diterapkan, karena memiliki kelebihan dibandingkan dengan proses kimiawi. Serta, lebih baik dari proses pengendapan (presipitation) kalau dikaitkan dengan kemampuan menstimulasikan perubahan $\mathrm{pH}$ dan konsentrasi logam beratnya. Dengan kata lain, penanganan logam berat dengan mikroorganisme relatif mudah dilakukan, murah dan cenderung tidak berbahaya bagi lingkungan (Bozkurt, dkk., 2014).

\section{Kesimpulan}

Konsentrasi logam timbal pada air laut di pelabuhan desa Paranggi kecamatan Ampibabo yaitu berkisar antara 0,4869 mg/L - 0,5304 $\mathrm{mg} / \mathrm{L}$, konsentrasi tersebut lebih tinggi jika dibandingkan dengan NAB logam Timbal yaitu $0,025 \mathrm{mg} / \mathrm{L}$. Untuk konsentrasi logam besi pada air laut di pelabuhan desa Paranggi kecamatan Ampibabo yaitu berkisar antara $0,2652 \mathrm{mg} / \mathrm{L}-0,3070 \mathrm{mg} / \mathrm{L}$, konsentrasi tersebut lebih tinggi jika dibandingkan dengan NAB logam besi yaitu $0,01 \mathrm{mg} / \mathrm{L}$.

\section{Ucapan Terima Kasih}

Penulis mengucapkan terima kasih kepada kepala laboran laboratorium Agroteknologi FAPERTA dan semua pihak yang telah membantu dalam pelaksanaan penelitian ini.

\section{Referensi}

Alamsyah. (2010). Distribusi logam berat timbal $(\mathrm{Pb})$ dan kromium (Cr) dalam air Muara Sungai Poboya. Skripsi. Palu: Universitas Tadulako,

Amriani, Hendrarto, B., \& Hadiyarto, A. (2011). Bioakumulasi logam berat timbal $(\mathrm{Pb})$ dan seng $(\mathrm{Zn})$ pada kerang darah (Anadara granosa) dan kerang bakau (Polymesoda bengalensis) di perairan teluk Kendari. Jurnal ilmu lingkungan, 9(2), 4550.

Begum, A., Krishna, H., \& Khan, I. (2009). Analysis of heavy metals in water, sediments and fish samples of madivala lakes of bangalore, karnataka. International Journal of Chem Tech Research, 1(2), 245-249.

Bustanul, Deswati, A., \& Loekman, U. (2012). Analisis kandungan logam $\mathrm{Cd}, \mathrm{Cu}, \mathrm{Cr}$ dan $\mathrm{Pb}$ dalam air laut di sekitar perairan bungus teluk kabung Kota Padang. Jurnal Teknik Lingkungan, 9(2), 139-145.

Bozkurt, E., eliri, O., \& kesiktas, M. (2014). Analysis of heavy metals in seawater samples collected from beaches of asian side of istanbul. Journal of Recreation And Tourism Research, 1(1), 39-47.

Effendi, H. (2003). Telaah kualitas air. Yogyakarta: Kanisius. 
Gultom, J., Amin, B., \& Ikhwan, Y. (2011). Kandungan logam berat timbal $(\mathrm{Pb})$ dan tembaga $(\mathrm{Cu})$ pada air laut dan sedimen di perairan batubara provinsi Sumatera Utara. Jurnal Kimia, 3(2) 1-10.

Hutagalung, H. P. (2001). Logam berat dalam lingkungan laut. Jurnal Perikanan, 9(1), 11-20.

Ika. (2012). Analisis logam besi (Fe) dalam air laut di wilayah pesisir pelabuhan ferry Taipa kecamatan Palu Utara. Skripsi. Palu: Universitas Tadulako.

Irvan, P., \& Rusian. (2013). Studi kandungan dan industri spasial logam berat timbal pada sedimen dan kerang (Anadara sp) diwilayah pesisir kota Makassar. Jurnal kesehatan lingkungan, 2(5), 30-45.

Murtini, J., \& Rosmawaty. (2006). Kandungan logam berat pada kerang kepah (meritrix meritrix) dan air laut di perairan Banjarmasin. Jurnal Perikanan, 8(2), 177184.

Parawita, D., Insafitri, \& Nugraha, W. A. (2009). Analisis konsentrasi logam berat timbal $(\mathrm{Pb})$ di muara sungai Porong. Jurnal Kelautan, 2(2), 34-42.

Perez-Lopez, Alonso, M. C., Melgar, Novoa., Valinas \& Mear. J. (2003). Assessment of heavy metal contamination of seawater and marine, patella vulgata 1 ., from notrhwest Spain. Jurnal of Environmental Science And Health, 38(12), 2845-2856.
Rahman, A. (2006). Kandungan logam berat timbal $(\mathrm{Pb})$ dan kadmium $(\mathrm{Cd})$ pada beberapa jenis krustasea di pantai batakan dan takisung kabupaten tanah laut Kalimantan Selatan. Jurnal Bioscientiae, 3(2), 93-101.

Rusmawan, C. A., Onggo, D., \& Mulyani, I. (2011). Analisis kolorimetri kadar besi(III) dalam sampel air sumur dengan metoda pencitraan digital. Jurnal Prosiding Simposium Nasional Inovasi Pembelajaran dan Sains, 2(12), 1-6.

Siaka. (2008). Korelasi antara kedalaman sedimen di pelabuhan Benoa dan konsentrasi logam berat $\mathrm{Pb}$ dan $\mathrm{Cu}$. Jurnal Kimia, 2(2), 61-70.

Sudarmaji, J., Mukono, \& Corie. (2006). Toksikologi logam berat B3 dan dampaknya terhadap kesehatan. Jurnal Kesehatan Lingkungan, 2(2), 129 -142.

Susiati, H., Yarianto SBS., Ali, A., \& Menri, Y. (2008). Kandungan logam berat $(\mathrm{Cu}, \mathrm{Cr}$, $\mathrm{Zn}$, dan $\mathrm{Fe}$ ) pada terumbukarang di perairan pulau panjang Jepara. Jurnal Pengembangan Energi Nuklir, 10(1), 59-66.

Sustrisno, C. T. (2002). Teknologi penyediaan air bersih. Yogyakarta: PT. Rineka cipta.

Tahril, Taba, P., Nafie, N. L., \& Noor, A. (2011). Analisis besi dalam ekosistem lamun dan hubungannya dengan sifat fisikokimia perairan pantai Kabupaten Donggala. Jurnal Natur Indonesia, 13(2), 105-111. 